\title{
Olfactory Ensheathing Cells Do Not Exhibit Unique Migratory or Axonal Growth-Promoting Properties after Spinal Cord Injury
}

\author{
Paul Lu, ${ }^{1,2}$ Hong Yang, ${ }^{1}$ Maya Culbertson, ${ }^{1}$ Lori Graham, ${ }^{1}$ A. Jane Roskams, ${ }^{3}$ and Mark H. Tuszynski ${ }^{1,2}$ \\ ${ }^{1}$ Department of Neuroscience, University of California at San Diego, La Jolla, California 92093, ${ }^{2}$ Veterans Affairs Medical Center, San Diego, California \\ 92161, and ${ }^{3}$ Department of Zoology, University of British Columbia, Vancouver, British Columbia, Canada V6T 1Z4
}

Olfactory ensheathing cells (OECs) have been reported to migrate long distances and to bridge lesion sites, guiding axonal regeneration after spinal cord injury (SCI). To understand mechanisms of OEC migration and axonal guidance, we injected lamina propria OECs $1 \mathrm{~mm}$ rostral and caudal to C4 SCI sites. One month later, OECs formed an apparent migrating cell tract continuously extending from the injection site through the lesion, physically bridging the lesion. Confocal immunolabeling demonstrated that, whereas this cell tract displaced host astrocytes, descending or ascending long tract axons did not preferentially extend into the cell tract and OECs failed to support bridging of corticospinal axons. Notably, the "bridging" tract of OECs formed within $1 \mathrm{~h}$ of cell injection, raising the possibility that cells passively spread from the pressure injection site rather than actively migrating. Control injections of bone marrow stromal cells (MSCs) or fibroblasts $1 \mathrm{~mm}$ from the lesion site also rapidly dispersed into the lesion cavity. Cell tracts extending into the lesion site were not seen when cells were injected either at low volumes, into spinal cord gray matter, or $3 \mathrm{~d}$ before or $9 \mathrm{~d}$ after SCI. OECs proliferated in injection sites, cell tracts, and lesion sites, indicating that OECs can also accumulate through cell proliferation. Thus, OECs do not appear to exhibit significant migratory properties when grafted to the spinal cord, exhibit no detectable difference in promoting axon growth into a SCI site compared with MSCs or fibroblasts, and do not support bridging of corticospinal axons beyond a dorsal column lesion.

Key words: olfactory ensheathing cells; spinal cord injury; migration; axon growth; axon guidance; proliferation

\section{Introduction}

Olfactory ensheathing cells (OECs) are glial cells that ensheath the axons of olfactory receptor neurons extending from the olfactory epithelium to the olfactory bulb (Doucette, 1995; Chuah and West, 2002). OECs have been reported to guide and support the entry and growth of axons from newly born olfactory receptor neurons to their target CNS tissue after transection of the olfactory nerve (Graziadei and Monti Graziadei, 1980; Doucette et al., 1983; Doucette, 1990). Because of these proposed axon growthpromoting properties, OECs have been extensively studied and transplanted into the injured spinal cord or the dorsal root entry zone in an attempt to promote axonal regeneration (RamonCueto and Nieto-Sampedro, 1994; Li et al., 1997, 1998, 2004; Ramon-Cueto et al., 1998, 2000; Navarro et al., 1999; Imaizumi et al., 2000a,b; Boruch et al., 2001; J. Lu et al., 2001, 2002; Nash et al., 2002; Pascual et al., 2002; Ruitenberg et al., 2002, 2003, 2005; Takami et al., 2002; Gomez et al., 2003; Keyvan-Fouladi et al.,

Received July 28, 2006; accepted Sept. 17, 2006.

This work was supported at the University of California at San Diego by National Institutes of Health Grant R01 NS09881, the Veterans Administration, the Canadian Spinal Research Organization, the Swiss Institute for Research into Paraplegia, and the Neuroscience Microscopy Shared Facility. This work was supported in Vancouver by the International Spinal Research Trust and the Christopher Reeve Paralysis Foundation.

Correspondence should be addressed to Mark H. Tuszynski, Department of Neuroscience, University of California at San Diego, La Jolla, CA 92093-0626. E-mail: mtuszynski@ucsd.edu.

DOI:10.1523/JNEUROSCI.3264-06.2006

Copyright $\odot 2006$ Society for Neuroscience $\quad$ 0270-6474/06/2611120-11\$15.00/0
2003; Plant et al., 2003; Resnick et al., 2003; Verdu et al., 2003; Andrews and Stelzner, 2004; Boyd et al., 2004; Cao et al., 2004; Chuah et al., 2004; Garcia-Alias et al., 2004; Lee et al., 2004; Lopez-Vales et al., 2004, 2006; Pearse et al., 2004; Polentes et al., 2004; Ramer et al., 2004a,b; Riddell et al., 2004; Sasaki et al., 2004; Barakat et al., 2005; Collazos-Castro et al., 2005; Fouad et al., 2005; Richter et al., 2005; Moreno-Flores et al., 2006). Many of the above studies report that OECs promote axonal regeneration and, in some cases, functional recovery, although controversy exists (Gomez et al., 2003; Ramer et al., 2004b; Riddell et al., 2004; Steward et al., 2006). Nonetheless, cells referred to as OECs have recently been implanted into $\sim 1000$ human patients with spinal cord injury (Huang et al., 2003; Dobkin et al., 2006).

Initial studies hypothesized that migratory properties of OECs account in part for their "repair" qualities, because OECs were found to migrate and associate with extending axons in the lesioned spinal cord (Ramon-Cueto and Nieto-Sampedro, 1994; Li et al., 1997, 1998; Ramon-Cueto et al., 1998, 2000; Boruch et al., 2001). For example, in some studies, OECs were injected $1 \mathrm{~mm}$ rostral and caudal to a lesion site, and it was reported that OECs migrated longitudinally as far as $1.5 \mathrm{~cm}$ from the host/lesion interface (Ramon-Cueto et al., 1998). Furthermore, colocalization of migrating OECs and regenerating corticospinal and serotonergic axons was proposed to provide permissive conditions for axon bridging beyond the lesion site (Ramon-Cueto et al., 1998, 2000). 
The present study originally sought to identify molecular mechanisms potentially underlying migratory properties of OECs. Well characterized OECs derived from lamina propria were genetically modified to express the reporter gene green fluorescent protein (GFP) to enhance tracking into sites of midcervical spinal cord injury (Au and Roskams, 2002, 2003; Ramer et al., 2004a). Unexpectedly, we failed to find unique migratory properties of these cells when implanted into spinal cord lesion sites, and we further find that grafted tracts of cells tend to displace established spinal pathways rather than exhibiting unique axon growth-promoting properties.

\section{Materials and Methods}

Cell culture. Lamina propria OECs were harvested from the olfactory mucosa of postnatal day 5 Fischer 344 rats, as described previously (Au and Roskams, 2003; Ramer et al., 2004a). Briefly, the entire olfactory mucosa, including turbinates and septum, was dissected from 8-10 pups, mechanically dissociated and digested using $0.6 \mathrm{mg} / \mathrm{ml}$ Collagenase D (Roche, Welwyn Garden City, UK), 3 U/ml dispase I (Roche), 15 $\mu \mathrm{g} / \mathrm{ml}$ hyaluronidase (Sigma, St. Louis, MO), $0.5 \mathrm{mg} / \mathrm{ml}$ bovine serum albumin (MP Biomedicals, Irvine, CA), and $100 \mathrm{U} / \mathrm{ml}$ DNase I (Sigma) for $1 \mathrm{~h}$ at $37^{\circ} \mathrm{C}$, before centrifugation and plating. Initial plating in MEMD-Valine (Invitrogen/BRL, Eugene, OR), 10\% fetal bovine serum (FBS), and $100 \mathrm{U} / \mathrm{ml}$ penicillin/streptomycin (P/S) (Invitrogen/BRL) was followed $4-5 \mathrm{~d}$ later by purification using anti-Thy 1.1-mediated complement lysis to remove contaminating fibroblasts. Cells were replated in DMEM/F12 (Invitrogen/BRL), 10\% FBS, and $100 \mathrm{U} / \mathrm{ml} \mathrm{P/S}$, allowed to grow for an additional 4-6 d, and were again subjected to Thy1.1mediated complement lysis.

Primary rat bone marrow stromal cells (MSCs) were isolated according to the method of Azizi et al. (1998). Briefly, the tibias and femurs of adult female Fischer 344 rats (3 months old, 150-165 g) were dissected. The ends of the bone were cut and $5 \mathrm{ml}$ of DMEM (Invitrogen/BRL) cell culture medium were injected into the central canal of the bone to extrude the marrow. Whole marrow cells were cultured at a density of $5-10 \times 10^{5}$ cells $/ \mathrm{cm}^{2}$ in $\alpha$-MEM medium (Invitrogen/BRL) supplemented with $20 \% \mathrm{FBS}$ and P/S. After $24 \mathrm{~h}$, nonadherent cells were removed and the medium was changed every other day until cells became confluent.

Primary cultures of rat fibroblasts were generated from skin biopsies of adult female Fischer 344 rats as described previously (Tuszynski et al., 1996) and maintained in standard medium (DMEM with high glucose; Invitrogen/BRL) containing 10\% fetal bovine serum and penicillin/ streptomycin.

Transduction of primary cells with the GFP reporter gene. To monitor grafted cell migration in vivo, primary OECs, MSCs, and fibroblasts were transduced with the jellyfish GFP reporter gene as described previously (Lu et al., 2005). Briefly, the retroviral vector plasmid DNA pLXSN-GFP was transfected into the stable viral producer line PA317 using the ecotropic packaging cell line psi-2, as described previously (Tuszynski et al., 1996). The virus collected from $24 \mathrm{~h}$ conditioned medium was used to infect either primary OECs, MSCs, or fibroblasts at early passage (p1p2). GFP-expressing OECs and MSCs were analyzed and sorted following standard procedures by a fluorescent-activated cell sorting scan directed to detection of GFP fluorescence, with a standard excitation wavelength of $488 \mathrm{~nm}$. GFP-expressing fibroblasts were purified by G418 selection as described previously (Tuszynski et al., 1996).

Assessment of OEC purity. To assess purity of OECs before transplantation, small aliquots of cells at passage 6 were seeded into 24 -well plates for $24 \mathrm{~h}$ then fixed in $4 \%$ paraformaldehyde for p 75 low affinity neurotrophin receptor immunocytochemical labeling (see below, histology and immunocytochemistry) (Au and Roskams, 2003; Jani and Raisman, 2004). The number of p75 and GFP double-labeled cells was then quantified in five randomly selected fields at $400 \times$ under a fluorescence microscope, and divided by the total number of GFP-expressing OECs in that field, to obtain the mean percentage of cells expressing p75.

Preparation of cells for transplantation. GFP-expressing OECs, MSCs, and fibroblasts at passages $5-7$ were harvested with $0.25 \%$ trypsin/ $1 \%$
EDTA when they reached $80-90 \%$ confluence. Cell suspensions were prepared at a concentration of $100,000 \mathrm{OECs} / \mu \mathrm{l}, 75,000 \mathrm{MSCs} / \mu \mathrm{l}$, and 75,000 fibroblasts/ $\mu \mathrm{l}$ in sterile PBS (Invitrogen) and maintained on ice for transplantation.

Surgery. A total of 66 adult female Fischer 344 rats (160-200 g) were subjects of this study. National Institutes of Health (NIH) guidelines for laboratory animal care and safety were strictly followed. Animals had access to food and water ad libitum throughout the study. All surgery was done under anesthesia with a combination $(2 \mathrm{ml} / \mathrm{kg})$ of ketamine $(25$ $\mathrm{mg} / \mathrm{ml})$, rompun $(1.3 \mathrm{~g} / \mathrm{ml})$, and acepromazine $(0.25 \mathrm{mg} / \mathrm{ml})$.

A previously characterized cervical spinal cord dorsal column wireknife lesion model (Weidner et al., 2001; Lu et al., 2004, 2005) was used for this study. Briefly, a Kopf microwire knife (Kopf Instruments, Tujunga, CA) was stereotaxically positioned at the $\mathrm{C} 4$ spinal dorsal midline, then moved $0.6 \mathrm{~mm}$ left laterally and lowered $1.1 \mathrm{~mm}$ from the dorsal spinal cord surface. The knife blade was extruded $2.25 \mathrm{~mm}$ toward the midline, forming a $1.5 \mathrm{~mm}$ wide wire arc. The arc was raised $2 \mathrm{~mm}$ and was simultaneously met by a blunt glass rod that added compression from above to ensure full transection of axons in the dorsal columns bilaterally.

Immediately after completing the lesion, $0.75 \mu \mathrm{l}$ of OECs were stereotaxically microinjected into the spinal cord dorsal column midline, 1 $\mathrm{mm}$ rostral and $1 \mathrm{~mm}$ caudal to the wire-knife lesion site, at a depth of $0.75 \mathrm{~mm}$ using a pulled glass micropipette with an inner diameter of 40 $\mu \mathrm{m}$, connected to a Picospritzer II (General Valve, Fairfield, NJ). The cells were injected at a rate of $200 \mathrm{nl} / \mathrm{min}$. This injection delivered cells into dorsal column white matter near the interface with spinal gray matter (eight injections in four subjects killed 1 month after cell injection). Comparison was also made to subjects that received direct OEC injections in the acute lesion cavity (injections into lesion sites in four animals killed 1 month after cell injection; volume $1.5 \mu$ l cells/lesion site).

After obtaining early experimental results (see Results), we added several control groups to further assess cell injection paradigms in this experiment. To control for the possibility that pressure cell injections might permit cells to track down a pathway of least resistance at the interface of white and gray matter toward the lesion site, or through diminished resistance along tracts of white matter, one control group received injections of OECs confined entirely within dorsal gray matter, $0.8 \mathrm{~mm}$ lateral to midline, $0.6 \mathrm{~mm}$ ventral to the dorsal spinal cord surface, and $1 \mathrm{~mm}$ rostral and caudal to the lesion site (four injections in two subjects). To further address the possibility that injection under pressure might cause cells to rapidly diffuse down a path of least resistance toward the lesion site rather than migrate at slower rates over time, the time course of OEC distribution from the site of injection toward the lesion cavity was examined; $0.75 \mu \mathrm{l}$ of OECs were injected in the dorsal column midline at a depth of $0.75 \mathrm{~mm}, 1 \mathrm{~mm}$ rostral and $1 \mathrm{~mm}$ caudal to the lesion site, and subjects were perfused at time points of $1,3,12$, and $24 \mathrm{~h}, 3 \mathrm{~d}$, and $7 \mathrm{~d}$ postinjection (four injections in two subjects at each time point). To provide an additional control for the possibility that cell injection under pressure favored passive cell diffusion down a low-pressure gradient, a very small volume of cells $(50 \mathrm{nl})$ was slowly injected over 5 min into the dorsal white matter midline at a depth of $0.75 \mathrm{~mm}$, at a distance $1 \mathrm{~mm}$ rostral and $1 \mathrm{~mm}$ caudal to the lesion site (12 injections in six subjects).

To further control for the possibility that OECs diffused rapidly down a low-pressure gradient that existed immediately after lesion placement, $0.75 \mu \mathrm{l}$ of OECs were injected either $3 \mathrm{~d}$ before lesion placement (before a low pressure gradient could exist), or $9 \mathrm{~d}$ postlesion (a time point at which an acute lesion-related low-pressure gradient would resolve). Cells were injected into the dorsal column midline at a depth of $0.75 \mathrm{~mm}$, and a distance $1 \mathrm{~mm}$ rostral and $1 \mathrm{~mm}$ caudal (eight injections in four subjects at each time point).

To address the possibility that OECs respond to migratory signals acting over a distance, OECs were injected at greater distances from the lesion site: $0.75 \mu \mathrm{l}$ of OECs were injected $3 \mathrm{~mm}$ rostral and $3 \mathrm{~mm}$ caudal to the lesion site, in the spinal cord midline at a depth of $0.75 \mathrm{~mm}$ (four injections in two subjects). OECs were also injected into the dorsal column white matter of intact animals to examine cell distribution in the noninjured environment (injections at the $\mathrm{C} 4$ level, spaced $2 \mathrm{~mm}$ apart in 
the rostral-caudal dimension, and injected into the dorsal column midline at a depth of 0.75 $\mathrm{mm}$; four injections in two subjects).

Finally, to determine whether either cell migration or passive cell diffusion from the injection site was a characteristic unique to OECs, additional animals received injections of either bone marrow stromal cells (MSCs) or fibroblasts using the same paradigm used for OEC injections. Subjects underwent C4 dorsal column wire knife lesions and received injections of $0.75 \mu \mathrm{l}$ of MSCs or fibroblasts into the midline dorsal columns at a depth of $0.75 \mathrm{~mm}$, at a distance $1 \mathrm{~mm}$ rostral and $1 \mathrm{~mm}$ caudal to the lesion site ( $n=4$ injections in two subjects per condition per time point). Subjects were killed $1,3,12$, and $24 \mathrm{~h}, 3 \mathrm{~d}$, and $7 \mathrm{~d}$ postinjection for MSCs, or $1 \mathrm{~h}, 3 \mathrm{~h}$, and $3 \mathrm{~d}$ postinjection for fibroblasts.

Unless stated otherwise, subjects were killed $7 \mathrm{~d}$ after cell injection.

To examine proliferation of grafted OECs in vivo, bromodeoxyuridine (BrdU; Sigma) was injected intraperioneally daily, $40 \mathrm{mg} / \mathrm{kg}$ in sterile saline, for five consecutive days beginning $1 \mathrm{~d}$ postlesion. BrdU was injected intraperitoneally in four subjects that received OEC implants into dorsal column white matter, 1 $\mathrm{mm}$ rostral and $1 \mathrm{~mm}$ caudal to the lesion site, at a depth of $0.75 \mathrm{~mm}$. Subjects were killed 1 week after lesion placement.

In subjects that received OEC injections into dorsal white matter immediately after spinal cord lesions, the corticospinal tract (CST) was anterogradely labeled using biotinylated dextran amine (BDA, MW 10,000; Invitrogen). Subjects received BDA injections 2 weeks before killing, and survived a total of 1 month postlesion. A total of $100 \mathrm{nl}$ of a $10 \%$ solution of $\mathrm{BDA}$ dissolved in $\mathrm{H}_{2} \mathrm{O}$ was injected into each of 18 sites spanning the rostral-to-caudal extent of the motor cortex with a Picospritzer (General Valve), using methods and injection coordinates reported previously (Lu et al., 2005). Ascending dorsal column sensory axons were transganglionically labeled with cholera toxin B subunit (CTB; List Biologic, Campbell, CA) injected into both sciatic nerves $3 \mathrm{~d}$ before perfusion, as described previously (Lu et al., 2005).

Histology and immunocytochemistry. At the end of each survival period, subjects were perfused with $4 \%$ paraformaldehyde in $0.1 \mathrm{M}$ phosphate buffer, $\mathrm{pH}$ 7.4. Spinal cords were dissected, postfixed overnight at $4^{\circ} \mathrm{C}$ and transferred to $30 \%$ sucrose for $72 \mathrm{~h}$. Sagittal sections of spinal cords from the cervical lesion site were cut on a cryostat set at $30 \mu \mathrm{m}$ thickness, and one of every seven sections was mounted on gelatincoated slides for Nissl staining. The remaining sections were serially collected into 24-well plates for immunocytochemistry.

Double or triple fluorescent immunocytochemistry was performed to assess cultured and grafted OEC purity, grafted OEC location, and migration at various survival times. After blocking nonspecific antibody reactions with $5 \%$ donkey serum for $1 \mathrm{~h}$ at room temperature, freefloating sections were incubated with primary antibodies directed against jellyfish GFP [polyclonal (rabbit or goat) antibody from Invitrogen at 1:1,500 to label GFP transduced OECs, MSCs, and fibroblasts], p75 [polyclonal (rabbit) antibody from Sigma at 1:100 to determine purity of OECs], GFAP [monoclonal antibody from Chemicon (Temecula, CA) at 1:1,000 to label host tissue astrocytes], neurofilament (NF; RT97 monoclonal antibody from Chemicon at 1:3,000 to label host tissue axons), serotonin (5-HT; monoclonal antibody from Chemicon at 1:15,000 to label raphespinal axons), CTB [polyclonal (goat) antibody from List Biologic at 1:5,000 to label dorsal column sensory axons], BrdU (monoclonal antibody from Chemicon at 1: 400 to label dividing cells), and Alexa 594-conjugated streptavidin (to bind to BDA-labeled corticospinal tract axons) overnight at $4^{\circ} \mathrm{C}$. After washes, sections were incubated either
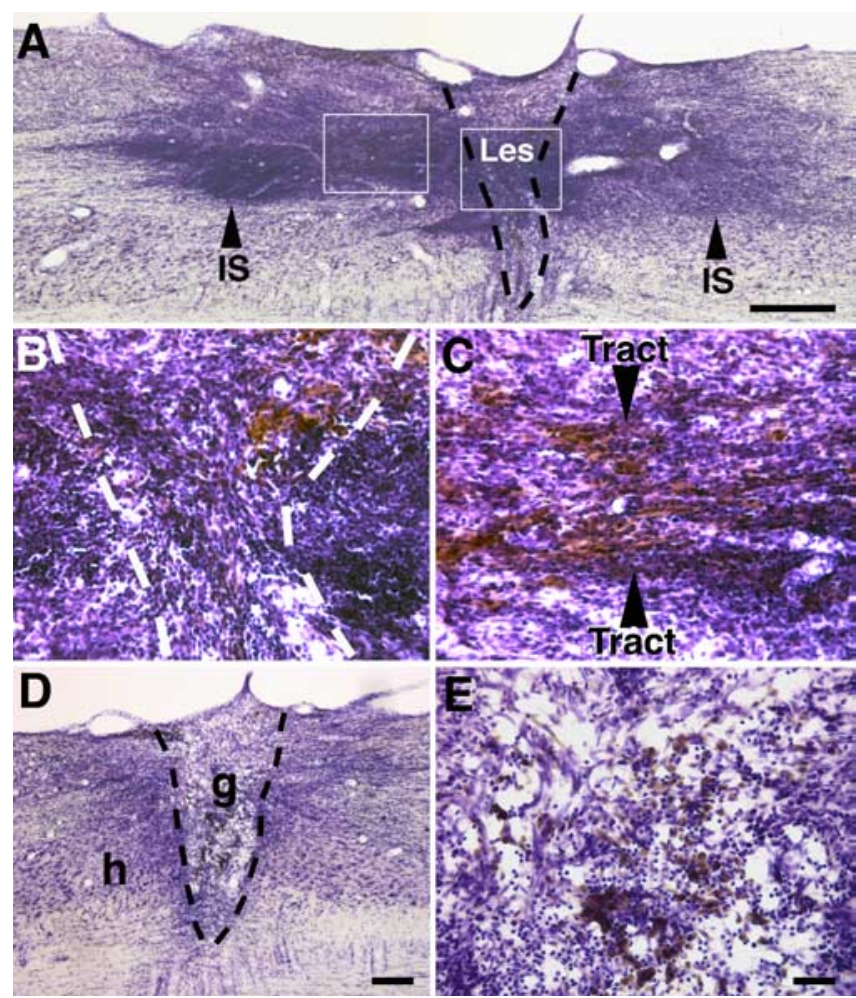

Figure 2. $\quad$ OEC injection $1 \mathrm{~mm}$ from lesion site. $\boldsymbol{A}$, Nissl-stained section demonstrating the morphology of rostral and caudal OEC injection sites (IS; arrowhead) and lesion site (Les; outlined by dashed lines). $\boldsymbol{B}-\boldsymbol{C}$, Higher magnification of boxed areas in $\boldsymbol{A}$, showing filling of lesion site with $\mathrm{OECs}$ injected $1 \mathrm{~mm}$ distantly $(\boldsymbol{B})$, and a cell tract (Tract; arrow) extending caudally from the injection site (IS; C). D, Graft/lesion morphology in a control subject wherein $0 \mathrm{EC}$ s were directly injected into lesion site (outlined by dashed lines). $g$, Graft; $h$, host. $\boldsymbol{E}$, Higher magnification of lesion area in $\boldsymbol{D}$. Cells injected $1 \mathrm{~mm}$ away from the lesion site $(\boldsymbol{B})$ reconstitute a more regular cellular matrix than cells directly injected into lesion site $(\boldsymbol{E})$. Scale bars: $\boldsymbol{A}, 380 \mu \mathrm{m}$; (in E) $\boldsymbol{B}, \boldsymbol{C}, \boldsymbol{E}, 42 \mu \mathrm{m} ; \boldsymbol{D}, 208 \mu \mathrm{m}$. 

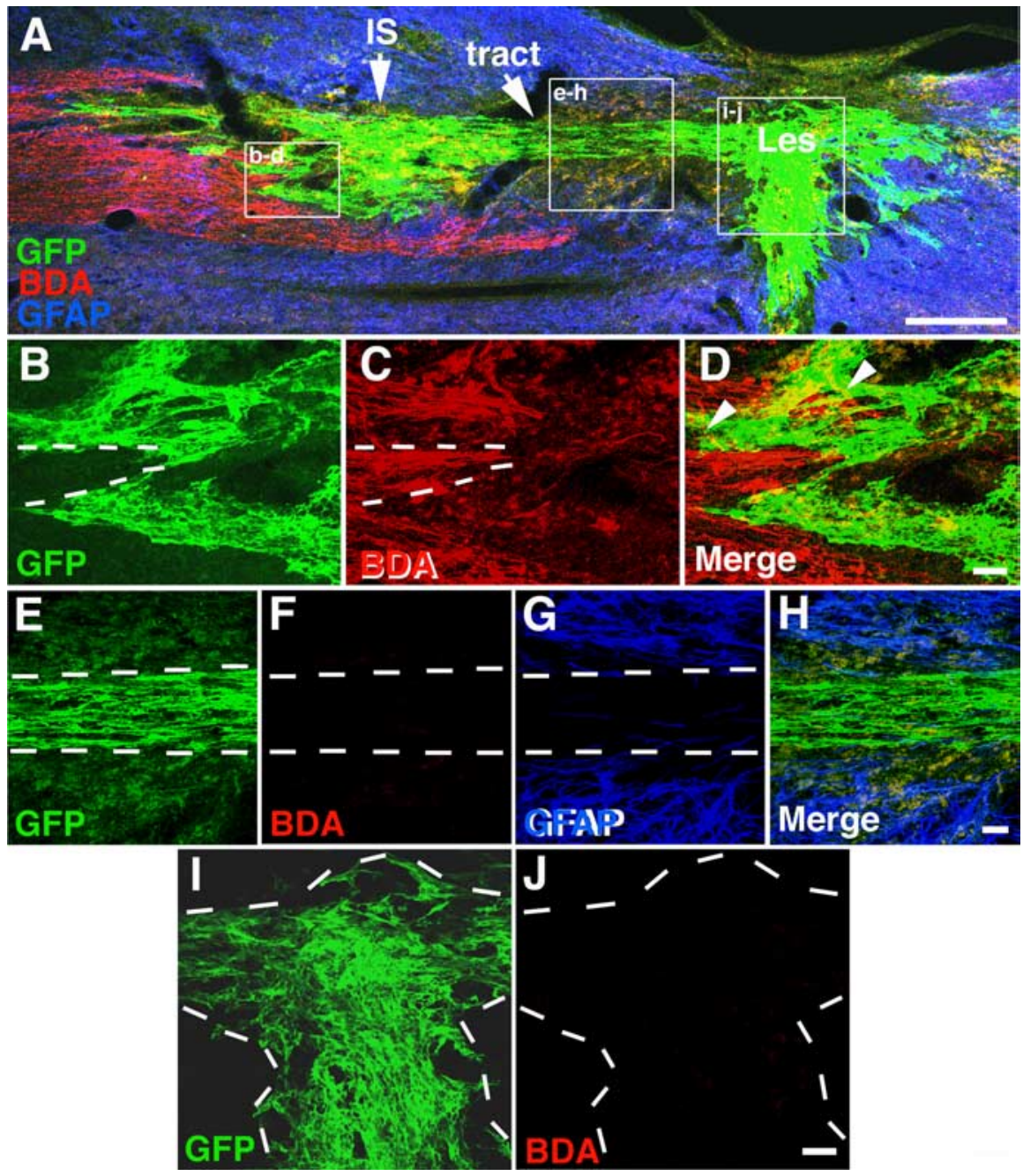

Figure 3. OEC Tract formation and relationship to corticospinal axons. $A$, Triple fluorescent immunolabeling for injected OECS (green; expressing GFP), host astrocytes (GFAP; blue) and corticospinal tract axons (red). OECs injected $1 \mathrm{~mm}$ rostral to the lesion site form a cell tract extending from injection site (IS) to lesion (Les), 4 weeks after injection. $\boldsymbol{B}-\boldsymbol{D}$, Higher magnification of confocal $Z$-stacks from left box in $\boldsymbol{A}$ indicates that parenchymal regions containing injected OECs (green) exhibit reduced labeling for corticospinal axons (red) compared with regions outside the OEC tract (e.g., region within dashed lines). Corticospinal axons are present outside main labeled $0 \mathrm{E}(\mathrm{Cract}(\boldsymbol{D}$, arrowheads). $\boldsymbol{E}-\boldsymbol{H}$, Higher magnification of middle box in $\boldsymbol{A}$. Corticospinal axons are not visible within $\mathrm{OEC}$ tract extending toward lesion cavity. In addition, GFAP labeling does not colocalize with the tract composed of longitudinally oriented $\mathrm{OECS}$, suggesting that $\mathrm{OECS}$ may displace host glia. $I, J$, Higher magnification of right box in $A$ shows no corticospinal axons (red) growing into and beyond the lesion site containing OECs (green). Scale bars: $\boldsymbol{A}, 260 \mu \mathrm{m} ; \boldsymbol{B}-J, 35 \mu \mathrm{m}$.

with Alexa 488, Alexa 594- or Cy5-conjugated donkey anti-mouse, donkey anti-rabbit, or donkey anti-goat secondary antibodies (1:150; Invitrogen) or biotinylated donkey anti-rabbit secondary antibody (for p75 labeling, 1:150; Vector Laboratories, Burlingame, CA) for $2.5 \mathrm{~h}$ at room temperature. After incubation with biotinylated secondary antibody, sections were incubated with streptavidian Alexa 594 (1:300; Invitrogen) at room temperature for another $2.5 \mathrm{~h}$. The sections were then washed, mounted on uncoated slides and coverslipped with Fluoromount G (Southern Biotechnology, Birmingham, AL).

Quantification of axon density within spinal cord lesion/graft site or within cell migration tract and host tissue. The density of NF-labeled axons penetrating spinal cord lesion/graft sites, or within cell tracts and adjacent host tissue, was quantified using NIH Image software analysis of immunolabeled sections, as described previously (Tuszynski et al., 1996). The margins of the lesion were determined from outlines of GFAP immunolabeling. Alexa594 fluorescent images of NF-labeled axons from two randomly selected parasagittal sections from each animal were captured using an Olympus (Tokyo, Japan) confocal microscope and a sample box size of $512 \times 512$ pixels, under a $10 \times$ objective. Images were converted into black and white using NIH Image software, and the number of pixels occupied by NF-labeled axons within (1) each cell tract, (2) the lesion/graft site, or (3) the surrounding host spinal cord parenchyma surrounding each "migrating" cell tract was measured and divided by sample area to obtain mean NFlabeled axon density per pixel. Comparison was made to subjects that received implants of either GFP-expressing MSCs or GFP-expressing fibroblasts into the lesion site, in sections taken from previous studies (P. Lu et al., 2001; Lu et al., 2005) ( $n=4$ animals per group surviving 1 month). Results are expressed as axon density per pixel \pm SEM.

GFP-expressing OECs that colocalized with BrdU were quantified in four subjects surviving for 1 week after grafting into midline dorsal column white matter $(0.75 \mathrm{~mm}$ depth). Two randomly selected $Z$-stack optical section images were acquired under a $60 \times$ high numerical aperture oil objective in each of five regions (rostral injection site, rostral cell tract, lesion site, caudal cell tract, and caudal injection site) in each subject, using an Olympus FluoView 1000 confocal microscope (see Fig. 9). GFP/ BrdU double-labeling of cells was determined from $Z$-stack images using Volocity software (Improvision, Coventry, UK) after threedimensional reconstruction, and was expressed as the percentage of total GFP-labeled cells that colocalized with $\mathrm{BrdU}$ (i.e., the percentage of dividing OECs).

Statistical analysis. In all quantification procedures, observers were blinded to the nature of the experimental manipulation. Multiple group comparisons were made using one-way ANOVA and a designated significance level of 95\%. Post hoc differences were tested by Fischer's least square difference. Data are presented as mean \pm SEM.

\section{Results}

OECs survive and extend in a cell tract toward the lesion site after rostrocaudal transplantation

P75 immunocytochemical labeling revealed that $97.6 \pm 0.4 \%$ of GFP-expressing OECs labeled for $\mathrm{p} 75$ before in vivo grafting (Fig. $1 A-C$ ). After transplantation 1 $\mathrm{mm}$ rostral and caudal to the $\mathrm{C} 4$ spinal cord injury site, OECs survived at all time points examined and expressed both GFP and p75 (Fig. 1D-E). Grafted MSCs and fibroblasts, and sections in which primary antibody was omitted, did not label for p75 (data not shown).

We reported previously that wire-knife lesions transect the cervical dorsal columns, including dorsal column sensory axons and dorsal corticospinal tract axons, and that cystic cavities form if cells are not transplanted (Weidner et al., 2001; Lu et al., 2003, 2004, 2005). After injection of OECs $1 \mathrm{~mm}$ rostral and $1 \mathrm{~mm}$ caudal to the lesion site immediately after placement of lesions, OECs readily survived and formed a continuous tract of cells extending from injection sites to completely fill the lesion cavities, assessed 1 month postlesion and grafting (Figs. 2-5). The apparent number and density of cells occupying the lesion site appeared greatest in subjects that received OEC implants rostral and caudal to the lesion site, rather than direct OEC injections 
into the lesion site, as reported previously (Fig. 2) (Richter et al., 2005). The size of the lesion cavity did not differ between animals receiving rostral/caudal cell injections or injections directly into the lesion site (Figs. 2-5).

The OEC tract displaces host axons and astrocytes, and does not appear to guide axons toward the lesion site

To address whether rostrocaudally transplanted OECs promote axon growth and regeneration into and beyond the lesion site, we labeled corticospinal axons with BDA and sensory axons with CTB. Corticospinal tract axons did not penetrate grafts in the lesion site (Fig. 3) and were never observed bridging beyond the caudal host-graft interface. Furthermore, corticospinal axons rostral to the lesion site did not exhibit an evident topographical association with GFP-labeled OECs on thin plane confocal images (Fig. 3). Occasional sensory axons penetrated the lesion/ graft site (Fig. 4). However, CTB-labeled sensory axons did not preferentially extend along the OEC tract, which was located more ventrally than the rostrally projecting dorsal column sensory axons (Fig. 4). OEC tracts did not contain GFAP-labeled astrocyte cell bodies or processes (Fig. 3).

Tracts of OECs contained a significantly lower mean density of NF-labeled axons compared with the adjacent spinal cord $(p<0.0001)$ (Fig. 5). Axons extended into lesion sites filled with OECs, indicating that OECs, like other cell types, can constitute a cellular matrix supportive of axon growth into a lesion site (Fig. 5). Nevertheless, the density of axons within the lesion site in rostrocaudally transplanted subjects, in subjects receiving OEC injection directly into the lesion center, and in subjects receiving implants of MSCs or fibroblasts, was similar (Fig. 5). Raphespinal axons (5-HT immunolabeled) were present neither in the linear OEC tract nor within lesion sites (Fig. 5), within the limits of sensitivity of fluorescent immunolabeling used in this experiment.

\section{Time course of OEC distribution in} tracts extending toward the lesion site Given the striking formation of OEC tracts extending from injection to lesion sites 1 month after acute cell injections $1 \mathrm{~mm}$ rostral and $1 \mathrm{~mm}$ caudal to the lesion site, we examined a set of temporal, spatial, and cellular controls to elucidate mechanisms underlying this apparent migratory behavior. Notably, the arrangement of injected OECs into a linear tract extending from the injection site to the lesion site was present $1 \mathrm{~h}$ after lesion/injection in both rostral and caudal directions (Fig. 6). In subjects killed $3 \mathrm{~h}$ after OEC
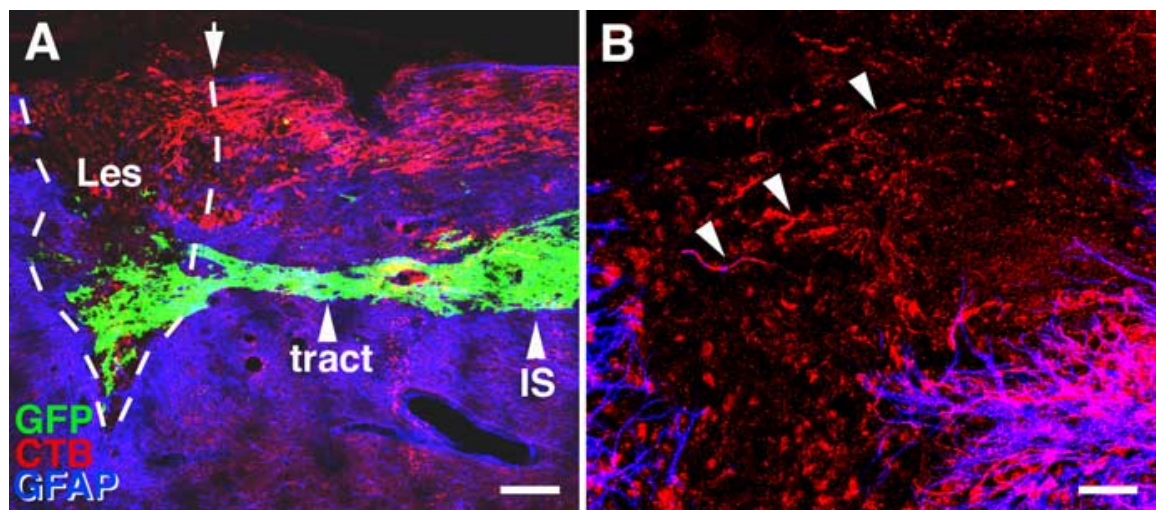

Figure 4. OEC tract formation and relationship to dorsal column sensory axons. $\boldsymbol{A}, 0 \mathrm{EC}$ s injected $1 \mathrm{~mm}$ caudal to the lesion (Les) also form a cell tract (tract) extending continuously from the injection site (IS) into the lesion. However, CTB-labeled axons (red) penetrate the lesion region not along tracts defined by $0 \mathrm{EC}$ cells, but directly across the dorsal host/graft interface (arrow). $\boldsymbol{B}$, Higher magnification of confocal Z-stacks demonstrates (TB-labeled sensory axons in lesion site (arrowheads), independent of OECs. Scale bars: $\boldsymbol{A}, 140 \mu \mathrm{m} ; \boldsymbol{B}, 45 \mu \mathrm{m}$.
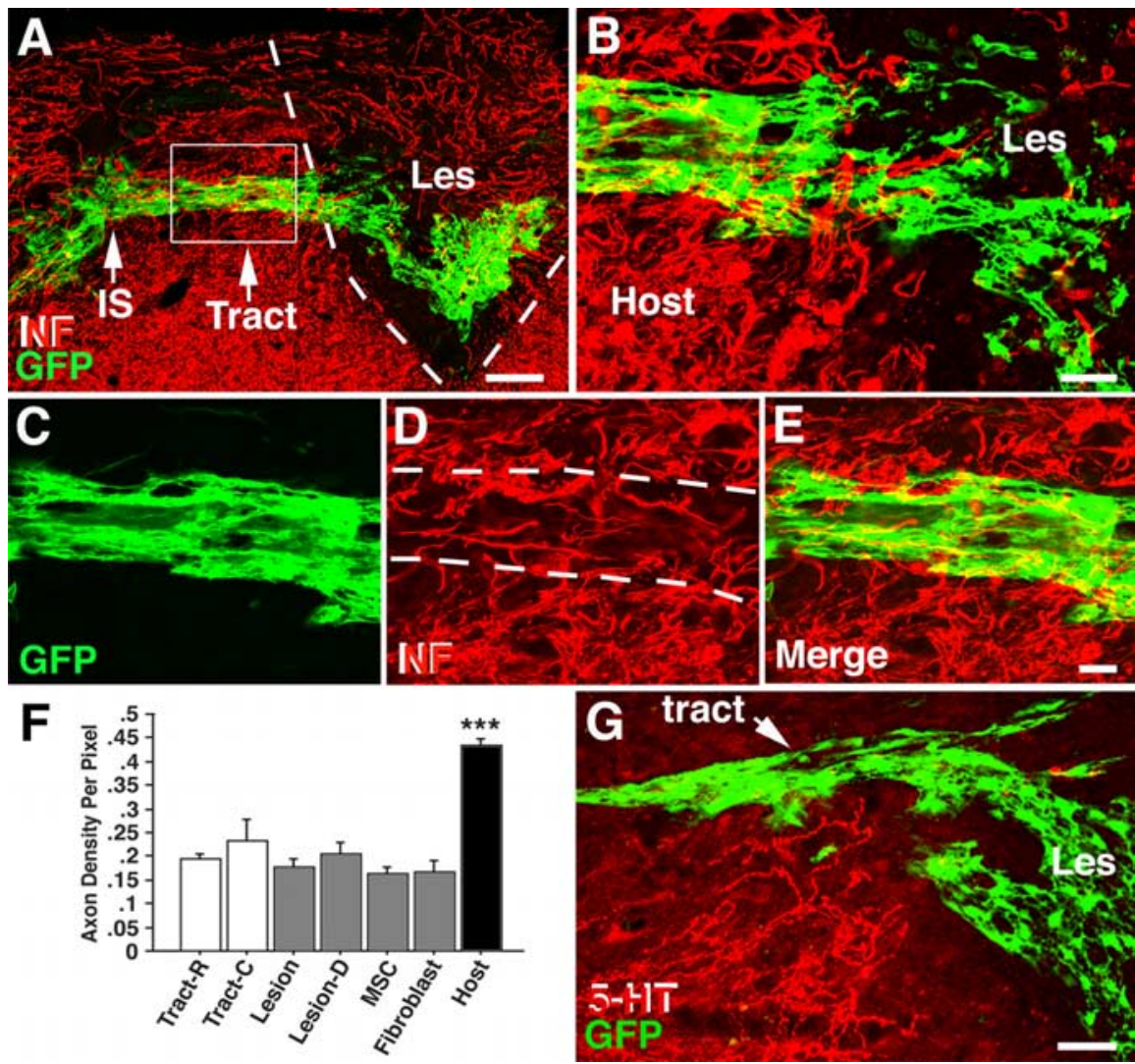

Figure 5. OEC tract formation and relationship to axons. $\boldsymbol{A}-\boldsymbol{E}, \mathrm{GFP}$ and NF double fluorescent immunolabeling. $\boldsymbol{A}, \mathrm{GFP}-$ expressing $\mathrm{OECS}$ (green) form a tract extending continuously between the rostral injection site (IS) and the lesion (Les). $\boldsymbol{B}$, Higher magnification of $\boldsymbol{A}$ shows that some NF-expressing axons (red) penetrate the lesion site from region of OEC tract, whereas other axons penetrate the lesion independent of $\mathrm{OEC}$ tract. $\boldsymbol{C}-\boldsymbol{E}$, Higher magnification of boxed area in $\boldsymbol{A}$ suggests that NF axon density is lower in $0 \mathrm{EC}$ tract than surrounding tissue. $\boldsymbol{F}$, Quantification of neurofilament axon density in $0 \mathrm{EC}$ cell tracts ( $R$, rostral; $C$, caudal) and in lesion site ( $D$, direct injection). Axon density in lesion/graft site does not differ among animals transplanted with $0 \mathrm{ECS}$, marrow stromal cells or fibroblasts. ${ }^{* * *} p<0.0001$. G, 5HT-labeled raphespinal axons (green) are not observed within $0 \mathrm{EC}$ tracts or lesion site (Les). Scale bars: $\boldsymbol{A}, 140 \mu \mathrm{m} ; \boldsymbol{B}-\boldsymbol{E}, \boldsymbol{G}, 32 \mu \mathrm{m}$. Error bars indicate SEM.

injection, more OECs were present in the lesion center, suggesting improved attachment of cells to the lesion cavity or ongoing shifts of OECs from injection sites to the lesion cavity via the cell tracts (Fig. 6). OECs remained small round and compact in the injection sites, cell tracts and lesion site (Fig. 6). By 12-24 h after 


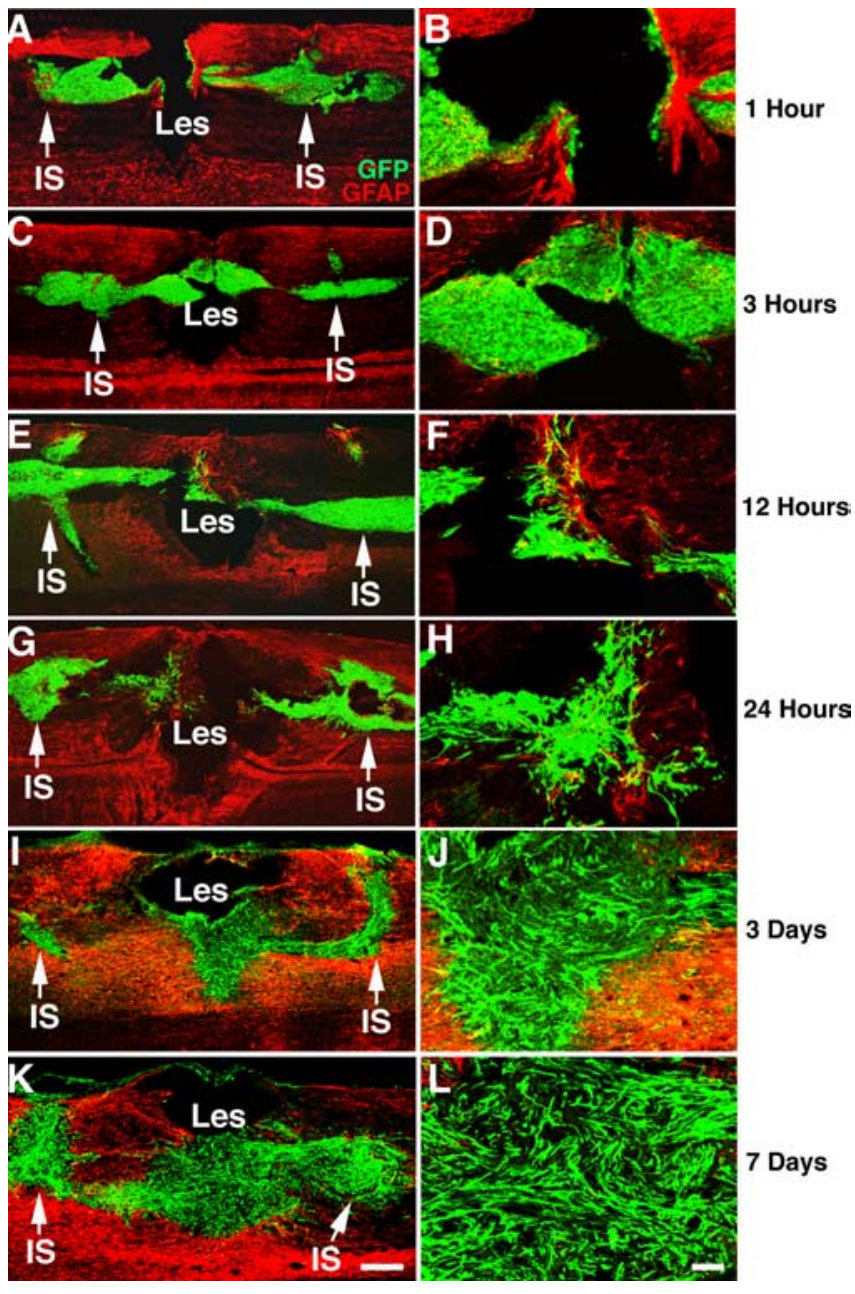

Figure 6. Time course of OEC tract formation and fill of lesion cavity. $\boldsymbol{A}-\boldsymbol{L}, \mathrm{GFP}$ (green) and GFAP (red) composite double-fluorescent immunolabeling over progressive times from lesion and cell grafting to death, demonstrating morphology of OEC tracts and filling of lesion cavity. Cell "tracts" extending from injection site (IS) to lesion site (Les) are present within $1 \mathrm{~h}$ of grafting. Over time, the lesion cavity fills, in part as a consequence of cell division (Fig. 9). By $3 \mathrm{~d}$ after injury, a cellular matrix of $0 \mathrm{EC}$ is well established in the lesion site. Scale bars: (in $\boldsymbol{K}) \boldsymbol{A}, \boldsymbol{C}$, $\boldsymbol{E}, \boldsymbol{G}, \boldsymbol{I}, \boldsymbol{K}, 350 \mu \mathrm{m}$; (in $\boldsymbol{L}) \boldsymbol{B}, \boldsymbol{D}, \boldsymbol{F}, \boldsymbol{H}, \boldsymbol{J}, \boldsymbol{L}, 50 \mu \mathrm{m}$.

cell injection, OECs were distributed more dorsoventrally within the lesion cavity (Fig. 6). In addition, OECs extended processes and reassumed more typical streaming (fibroblast-like) morphology. At these stages, the margins of the lesion site expanded in the rostrocaudal direction compared with very early time points postinjection as described previously (Fitch et al., 1999). By 3-7 d after cell injection, OECs almost filled the lesion cavity and cellular morphology became more compact, similar to the appearance of OECs remaining with injection sites and cell tracts (Fig. 6). Although OEC processes were randomly oriented within the lesion and injection site, cells were rostrocaudally oriented in the tracts leading to the lesion site. Rare OECs could be observed up to distances of $100 \mu \mathrm{m}$ outside the region of cell injection sites and tracts at time points of 3-7 d postinjury (Fig. 6), suggesting that a very small proportion of cells may migrate for short distances.

The OEC tract does not form when injected into other spinal cord locations or at low volumes

To further understand mechanisms underlying tract formation, OECs were transplanted in several different paradigms. These additional groups were killed $7 \mathrm{~d}$ after transplantation, a time point at which the groups described in the preceding section clearly exhibited cell distribution into tracts extending into the lesion site. When OECs were injected exclusively into gray matter located $1 \mathrm{~mm}$ rostral and $1 \mathrm{~mm}$ caudal to the lesion site immediately after injury, OECs remained in the injection site and did not form a tract between the injection and lesion site (Fig. 7). Thus, injection away from the gray/white matter interface and away from white matter tracts did not support formation of a tract into the lesion site. When a very low volume of cells was injected into the dorsal column white matter, $1 \mathrm{~mm}$ rostral and caudal to the lesion site immediately after injury, OECs remained primarily in the injection site and did not form a tract extending to the lesion site (Fig. 7). When OECs were injected into the dorsal columns at a distance $3 \mathrm{~mm}$ rostral and $3 \mathrm{~mm}$ caudal to the lesion site immediately after spinal cord injury, cells also remained in the injection site and did not form cell tracts (Fig. 7). When cells were injected into the dorsal column white matter in intact subjects, OECs remained primarily in the injection site (Fig. 7). These results indicate that the formation of a tract of OECs extending from the injection to the lesion site occurs only when cells are injected into white matter or at the gray/white interface, relatively close to the lesion site. Furthermore, OECs formed tracts to the lesion site only if grafted acutely after injury: among subjects that received injections of OECs into the dorsal columns either $3 \mathrm{~d}$ before injury or $9 \mathrm{~d}$ after injury, cells were detectable in the injection site but not in the lesion site (Fig. 7). When introduced $9 \mathrm{~d}$ after injury, some OECs aligned along the rostral-caudal orientation of white matter at the margins of the injection site, but migration was not evident and lesion cavities were devoid of cells (Fig. 7). At the site of one injection made $3 \mathrm{~d}$ before the $\mathrm{C} 4$ lesion, the caudal injection was located only $150 \mu \mathrm{m}$ from the subsequent lesion cavity rather than the intended $1 \mathrm{~mm}$; even in this case, the cavity was virtually devoid of OECs (Fig. 7).

\section{Cell tracts also form after implantation of marrow stromal cells or fibroblasts}

To address whether cell tract formation and filling of the lesion cavity is a unique characteristic of OECs after rostrocaudal transplantation, we transplanted GFP-expressing primary MSCs or fibroblasts $1 \mathrm{~mm}$ rostral and $1 \mathrm{~mm}$ caudal to an acute dorsal column lesion site. A time course study once again showed that cell tracts extending continuously from injection site to lesion cavity were present as early as $1 \mathrm{~h}$ postinjection after injection of either fibroblasts (Fig. 8A-F) or MSCs (Fig. 8G). Like OECs, both cell types filled the lesion cavity by 3-7 d. These results demonstrate that cell tract formation and filling of the lesion cavity can occur with other cell types, and are not unique to OECs.

\section{Cell proliferation contributes to lesion cavity filling}

To test whether proliferation of transplanted cells contributes to cell filling of the lesion cavity, we performed intraperitoneal injections of $\mathrm{BrdU}(50 \mathrm{mg} / \mathrm{kg} / \mathrm{d})$ on each of the first $6 \mathrm{~d}$ after cell injection/injury. Double-confocal immunolabeling revealed that $20-40 \%$ of GFP-expressing OECs colocalized with BrdU in cell injection sites, cell tracts, and lesions (Fig. 9). These results indicate that OECs proliferate after in vivo injection, likely contributing to expansion of cell number over time. 


\section{Host Schwann cells penetrate OEC grafts and associate with regenerating axons}

To examine the association of regenerating axons in OEC grafts with the local cellular milieu, we performed triple confocal high-resolution labeling for neurofilament, GFP (labeling implanted OECs), and the Schwann cell-specific marker 27C7 (Fig. 10) in grafts 1 month postimplantation. Most host axons present within grafts were associated with 27C7labeled host Schwann cells, which migrated into the lesion/graft site, paralleling previous observations in fibroblast (Jones et al., 2003) and bone marrow stromal cell (Lu et al., 2005) grafts in SCI lesion sites. As noted above, host axons in the graft did not exhibit preferential topographical association with GFP-labeled OECs.

\section{Discussion}

Findings of this study suggest that OECs exhibit neither unique migratory properties in relation to sites of spinal cord injury, nor enhanced axonal growth-promoting capabilities compared with other cellular substrates grafted into this lesion paradigm. Instead, we find that any of three cell types examined form continuous tracts extending into a spinal cord lesion site when injected $1 \mathrm{~mm}$ rostrally and caudally, and that the formation of these linear tracts is influenced by the timing, location, and volume of injection rather than cell type. Furthermore, we find that OECs do not support bridging of CST axons into or beyond a spinal cord lesion site. OECs did support, independent of tract formation, penetration of axons types other than the corticospinal system into a lesion cavity, but the degree of this axon growth did not differ from that of either fibroblast or bone marrow stromal cell grafts. OEC tracts displaced astrocyte processes, an effect that might reduce glial scars at lesion margins but could also alter blood-brain barrier repair after injury (Faulkner et al., 2004).

OECs have been described previously as cells that, in the adult, retain the ability to migrate toward the olfactory bulb after loss of axonal contact after olfactory nerve injury (Doucette, 1995). However, two recent studies indicate that OECs neither migrate nor proliferate in response to olfactory nerve injury, instead remaining as a conduit of cells that can guide regenerating axons of the olfactory nerve (Williams et al., 2004; Li et al., 2005). In this manner, they appear to function analogously to Schwann cells after a peripheral nerve injury. In addition, OECs actively phagocytose degenerating axons ( $\mathrm{Li}$ et al., 2005). It has been proposed that the maintenance of open OEC channels plays a role in facilitating growth of axons from newly regenerated receptor neurons to their targets within the olfactory bulb (Li et al., 2005).

OECs have been reported to migrate extensively in the injured $\boldsymbol{F}, 630 \mu \mathrm{m}$
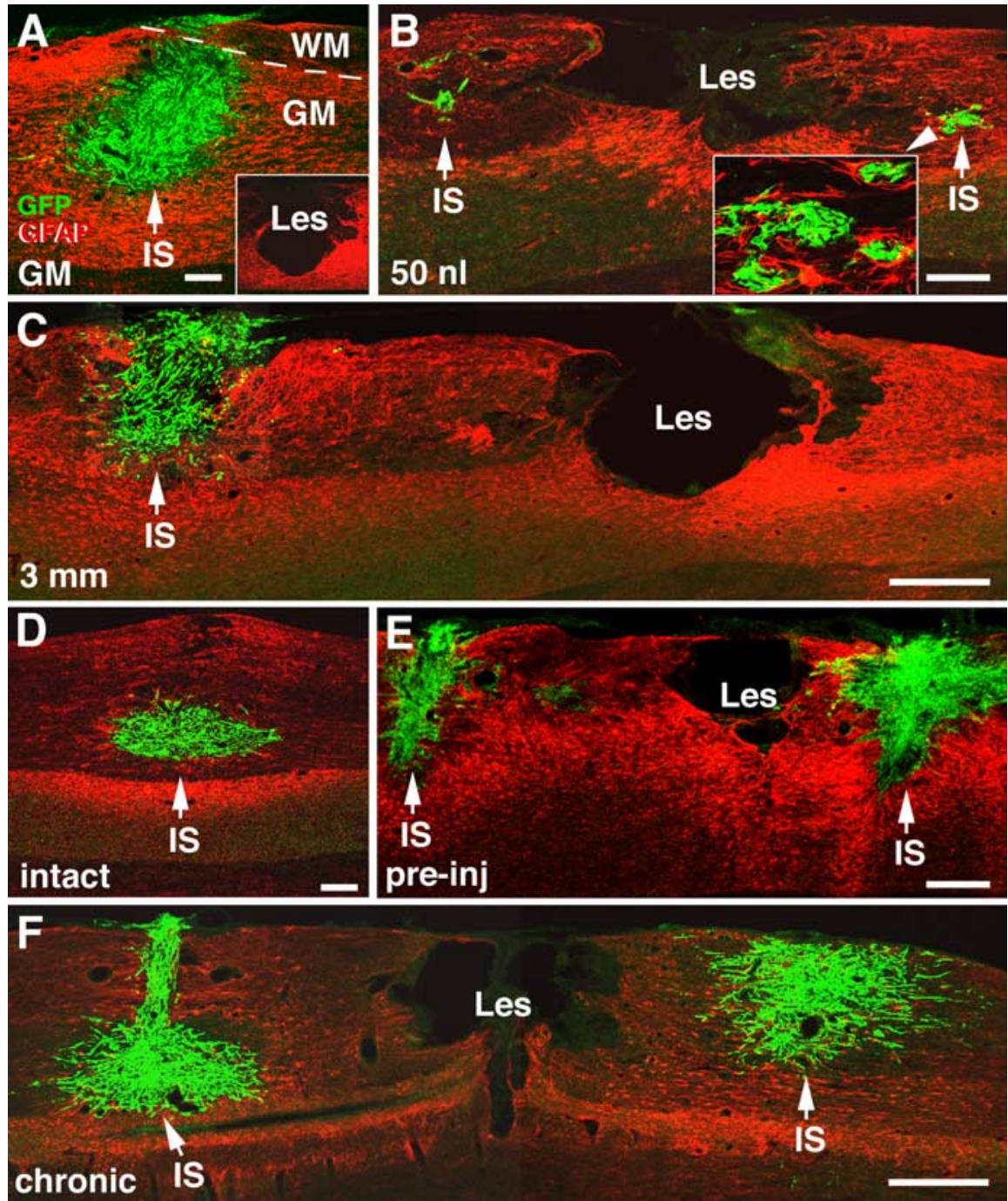

Figure 7. OECS do not form tracts after injection at greater distances from lesion, or after injection of small volumes. $A, 0 E C S$ (green) do not form tracts extending to lesion cavity when injected into gray matter (GM) rather than white matter (WM), $1 \mathrm{~mm}$ rostral or caudal to the lesion site (Les). GFAP labeling (red) indicates lesion margins; the lesion cavity is empty (inset). IS, injection site. $\boldsymbol{B}, 0 \mathrm{ECS}$ do not form tracts extending to lesion cavity when small volumes $(50 \mathrm{nl})$ are injected $1 \mathrm{~mm}$ rostral and $1 \mathrm{~mm}$ cauda tract fails to form and only a rare cell is present in the otherwise empty lesion cavity. No cells appear adjacent to the lesion cavity in cavity when injected $9 \mathrm{~d}$ after a lesion, $1 \mathrm{~mm}$ rostral or caudal to the lesion site. Scale bar: $\boldsymbol{A}, \boldsymbol{D}, 175 \mu \mathrm{m} ; \boldsymbol{B}, \boldsymbol{E}, 350 \mu \mathrm{m} ; \boldsymbol{C}$,

spinal cord, especially when transplanted rostrocaudally in proximity to a lesion site (Ramon-Cueto and Nieto-Sampedro, 1994; Li et al., 1998; Ramon-Cueto et al., 1998; Imaizumi et al., 2000a; Boruch et al., 2001; Keyvan-Fouladi et al., 2003; Resnick et al., 2003; Sasaki et al., 2004). It has been proposed that OECs might respond to signals or factors from injured neurons and their processes, therefore migrating preferentially toward an injury site (Ramon-Cueto et al., 1998; Boruch et al., 2001). However, based on our results, the formation of an OEC tract extending toward the lesion site from the site of grafting is most likely a pressure injection phenomenon caused by the rostrocaudal arrangement of glia and supporting tissue in spinal cord white matter. Indeed, there exists an extensive literature in the field of fluid flow dy- 


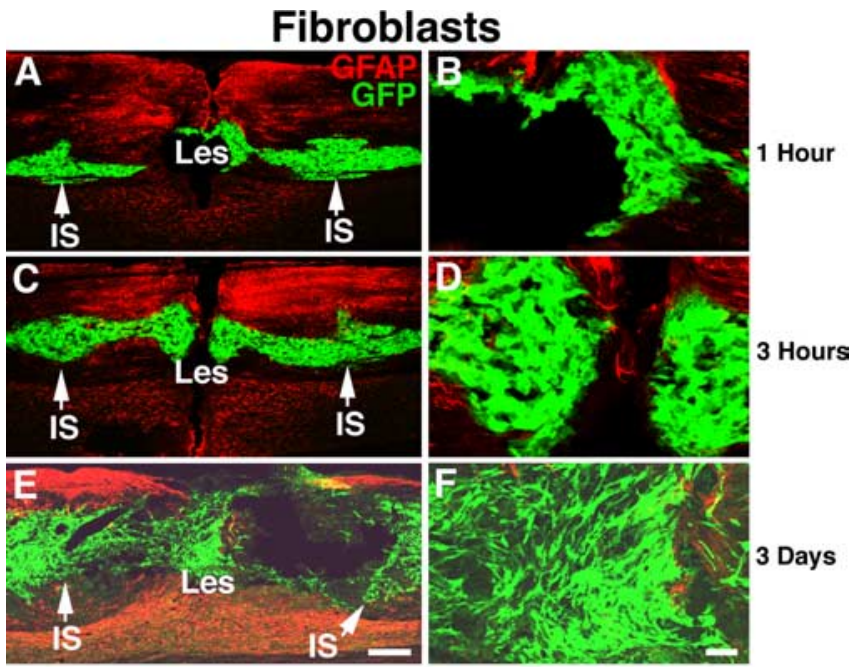

Marrow stromal cells

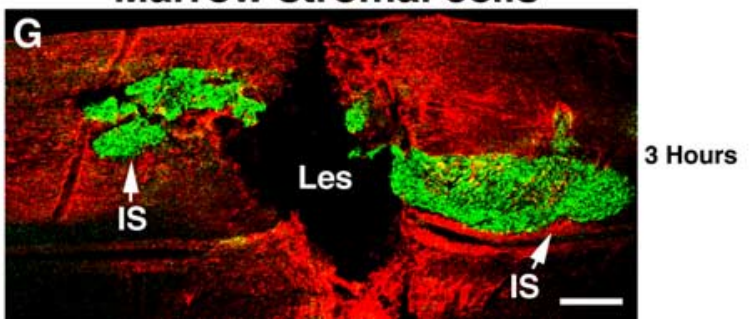

Figure 8. Other cell types form tracts to the lesion site when injected acutely after injury. $\boldsymbol{A}-\boldsymbol{F}$, GFP and GFAP double-fluorescent immunolabeling indicates that fibroblasts also form tracts extending from the injection site (IS) to the lesion cavity (Les) when injected into dorsal white matter, $1 \mathrm{~mm}$ rostral or caudal to the lesion site. The time course of cellular distribution and filling of the lesion cavity entirely parallels that of OECS and MSCs (data not shown). $\mathbf{G}$, Similar responses are observed after injection of bone marrow stromal cells (example of cells $3 \mathrm{~h}$ after injection is shown). Scale bars: $\boldsymbol{A}, \boldsymbol{C}, \boldsymbol{E}, \mathbf{G}, 350 \mu \mathrm{m} ; \boldsymbol{B}, \boldsymbol{D}, \boldsymbol{F}, 50 \mu \mathrm{m}$.

namics in the brain and spinal cord describing the preferential movement of mass along the longitudinal orientation of white matter tracts (Rosenberg et al., 1980; Zhang et al., 1992; Bjelke et al., 1995; Geer and Grossman, 1997; Wood et al., 1999). The extensive movement of cells and fluid along these tracts is a function of the longitudinal orientation of cells, axons and their myelin sheaths within white matter (Zhang et al., 1992; Bjelke et al., 1995; Geer and Grossman, 1997). After a lesion, an injected substance would likely diffuse along this longitudinal axis and down a low-pressure gradient toward a lesion site. Previous studies have not examined other cell types as controls for OECs, and have not examined very early time points after cell injection, likely contributing to the potentially mistaken attribution of unique migratory properties to OECs.

Previous studies reported migration of OECs over extensive distances beyond a spinal cord lesion site based in part on the use of Hoechst cell labeling (Ramon-Cueto and Nieto-Sampedro, 1994; Ramon-Cueto et al., 1998, 2000; Boruch et al., 2001; Resnick et al., 2003; Cao et al., 2004; Chuah et al., 2004). However, subsequent reports indicated that the Hoechst label leaks from transplanted cells, leading to spread of the label rather than the implanted cell, causing an artifactual appearance of cell migration (Iwashita et al., 2000; Ruitenberg et al., 2002; Andrews and Stelzner, 2004). Consistent with our present results in a spinal cord injury paradigm, we previously xenotransplanted GFPlabeled lamina propria OECs into a dorsolateral funiculus crush
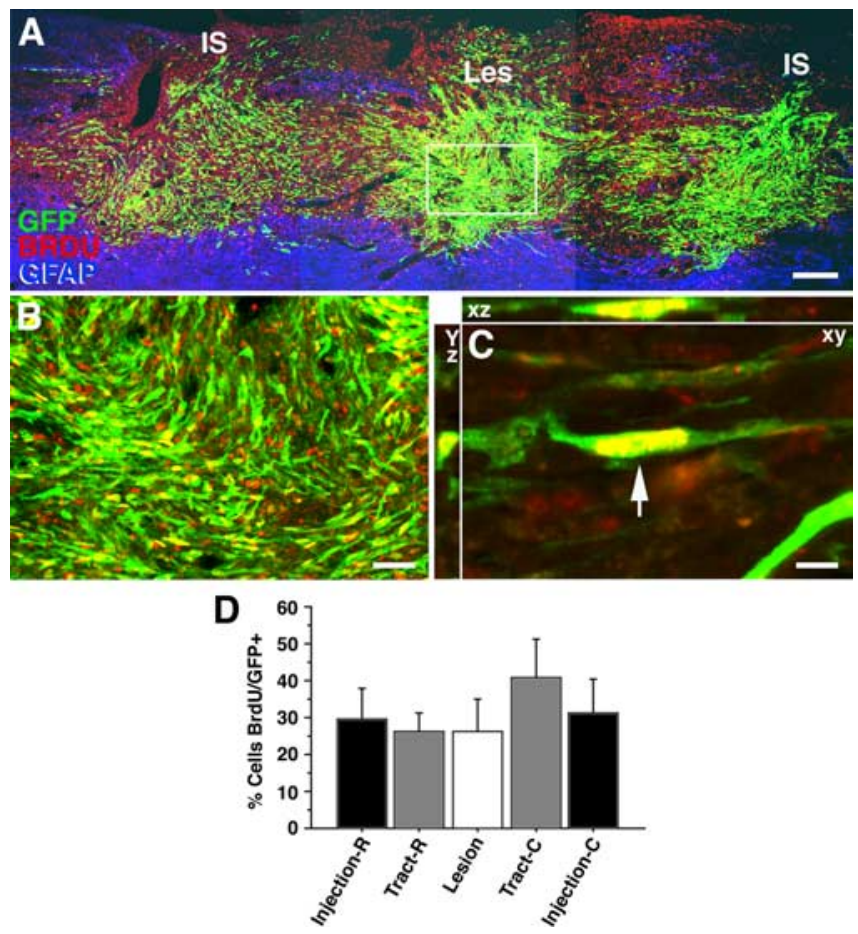

Figure 9. OEC proliferation 1 week postgrafting. A, Triple-fluorescent immunolabeling for injected OECs (green; expressing GFP), BrdU (red) and astrocytes (GFAP; blue). OECs proliferate in the rostral-caudal injection sites (IS), cell tracts and lesion site (Les). $\boldsymbol{B}$, Higher magnification of confocal Z-stacks from boxed area in $A$ shows that many GFP-expressing OECs colocalize with BrdU.C, $x y, x z$, and $y x$ plane images of typical GFP and BrdU double-labeled cells. Scale bars: $A, 175 \mu \mathrm{m} ; \boldsymbol{B}, 47$ $\mu \mathrm{m} ; C, 7 \mu \mathrm{m}$. D, Quantification demonstrates that $\sim 25 \%$ of GFP-labeled OECs have incorporated BrdU, $7 \mathrm{~d}$ postlesion (no significant groups differences at any site). Error bars indicate SEM.
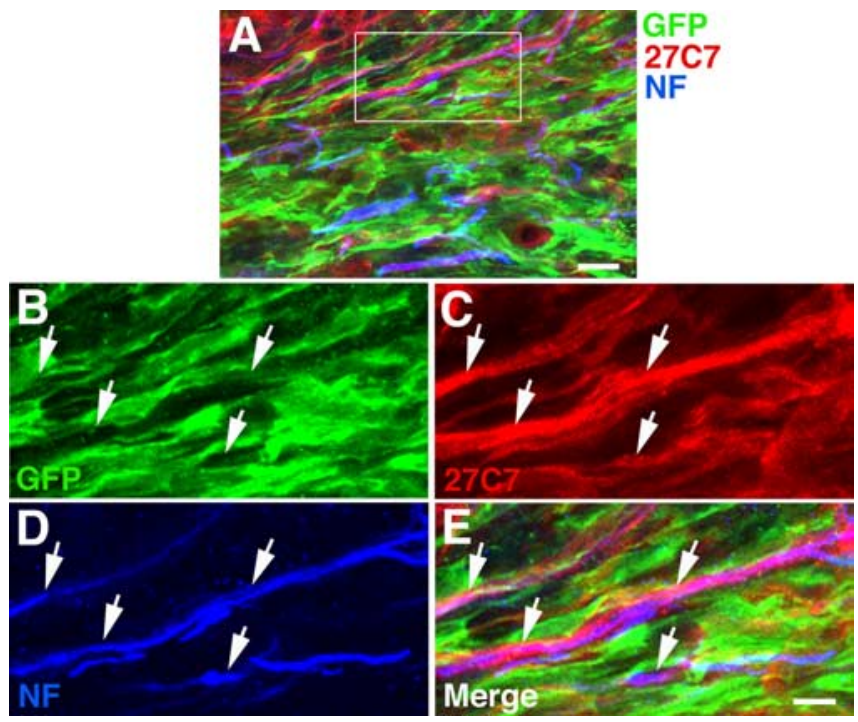

Figure 10. Schwann cells penetrate $0 \mathrm{EC}$ grafts in lesion cavity and associate with penetrating axons. A, Composite image of graft in lesion site 1 month after injury, containing grafted OECs labeled for GFP (green), host Schwann cells labeled with the Schwann cell-specific marker $27 C 7$ (red), and host axons labeled for NF (blue). $\boldsymbol{B}-\boldsymbol{E}$, The boxed region of $\boldsymbol{A}$ is shown at higher magnification. Host neurofilament-labeled axons penetrating the graft exhibit topographical association with Schwann cells (arrows). Scale bar: $A, 16 \mu \mathrm{m} ; \boldsymbol{B}-\boldsymbol{E}, 6 \mu \mathrm{m}$.

lesion, and found very limited migration of OECs from injection sites (Ramer et al., 2004a; Richter et al., 2005). We now find in a syngenic grafting paradigm, characterized by excellent graft cell survival, that OECs rarely migrate beyond their site of injection. 
Injection of OECs in this study did not support regeneration of corticospinal tract axons, and did not influence the growth of other axonal populations to extents differing from fibroblasts, bone marrow stromal cells or Schwann cells implanted into sites of injury in this and previous studies (Xu et al., 1995; Tuszynski et al., 1996; Liu et al., 1999; P. Lu et al., 2001, 2005). Furthermore, we observed no evidence that host axons used OEC tracts as "bridges" to enter or exit grafts, and tracts of OECs outside the lesion site were associated with an absence or reduction of axon density compared with the surrounding spinal cord. Instead, axons in the lesion site appear to preferentially associate with infiltrating Schwann cells after OECs have been transplanted into both focal and compressive SCI lesion models (Boyd et al., 2004; Ramer et al., 2004a). Such migration of endogenous Schwann cells is also observed after implantation of fibroblasts, bone marrow stromal cells, and stem cells into sites of SCI (Jones et al., 2003; Lu et al., 2005; Hill et al., 2006). Our findings contrast with previous reports that OECs promote bridging of axons into and beyond sites of SCI; it is possible that previous studies, which used either contusion or transection models, visualized spared rather than regenerating axons. For example, axons visualized as emerging from an OEC graft could instead be spared axons below a lesion that enter the graft from the caudal direction, rather than extending out of the graft and into the caudal spinal cord. Distinguishing whether an axon visualized below a lesion is extending rostrally or caudally is extremely complex in incomplete lesion models, particularly contusion models. We have directed considerable effort to assuring that the wire-knife lesions used in the present experiment completely transect corticospinal axons, by combining pressure applied downward with the upward movement of the wire knife against the dorsal columns and dorsal corticospinal tract (Weidner et al., 2001; Lu et al., 2004).

OECs normally support the extension of axons from newly born olfactory neurons in the olfactory bulb throughout life (Barnett, 2004). However, when olfactory axons are transected, these axons die back, the soma degenerates, and the axon does not regenerate (Graziadei and Monti Graziadei, 1980; Doucette et al., 1983; Doucette,1990; Williams et al., 2004; Li et al., 2005). Hence, in the mature olfactory bulb, OECs do not stimulate axonal regeneration; rather, they support axonal extension from newly born neurons throughout life. Similarly, in the spinal cord, we find that OECs provide a cellular matrix in a lesion site; this matrix is penetrated by Schwann cells, and collectively this matrix supports host axonal growth to a degree paralleling that of other grafted cell types. We do not find a propensity of OECs to migrate or otherwise support directed axonal extension or corticospinal tract regeneration. Findings of the present spinal cord injury model yield no evidence that OECs stimulate axon growth more extensively than other cell types, and yield no evidence that OECs support axonal regeneration beyond a lesion site. The rationale for using these cells in extensive human experimentation now underway is therefore unclear. The rationale for use of these cells in chronic human injury is further limited by a recent report that these cells fail to support functional recovery in rodent models of chronic SCI (Steward et al., 2006).

\section{References}

Andrews MR, Stelzner DJ (2004) Modification of the regenerative response of dorsal column axons by olfactory ensheathing cells or peripheral axotomy in adult rat. Exp Neurol 190:311-327.

Au E, Roskams AJ (2002) Culturing olfactory ensheathing glia from the mouse olfactory epithelium. Methods Mol Biol 198:49-54.

Au E, Roskams AJ (2003) Olfactory ensheathing cells of the lamina propria in vivo and in vitro. Glia 41:224-236.
Azizi SA, Stokes D, Augelli BJ, DiGirolamo C, Prockop DJ (1998) Engraftment and migration of human bone marrow stromal cells implanted in the brains of albino rats-similarities to astrocyte grafts. Proc Natl Acad Sci USA 95:3908-3913.

Barakat DJ, Gaglani SM, Neravetla SR, Sanchez AR, Andrade CM, Pressman Y, Puzis R, Garg MS, Bunge MB, Pearse DD (2005) Survival, integration, and axon growth support of glia transplanted into the chronically contused spinal cord. Cell Transplant 14:225-240.

Barnett SC (2004) Olfactory ensheathing cells: unique glial cell types? J Neurotrauma 21:375-382.

Bjelke B, England R, Nicholson C, Rice ME, Lindberg J, Zoli M, Agnati LF, Fuxe K (1995) Long distance pathways of diffusion for dextran along fibre bundles in brain. Relevance for volume transmission. NeuroReport 6:1005-1009.

Boruch AV, Conners JJ, Pipitone M, Deadwyler G, Storer PD, Devries GH, Jones KJ (2001) Neurotrophic and migratory properties of an olfactory ensheathing cell line. Glia 33:225-229.

Boyd JG, Lee J, Skihar V, Doucette R, Kawaja MD (2004) LacZ-expressing olfactory ensheathing cells do not associate with myelinated axons after implantation into the compressed spinal cord. Proc Natl Acad Sci USA 101:2162-2166.

Cao L, Liu L, Chen ZY, Wang LM, Ye JL, Qiu HY, Lu CL, He C (2004) Olfactory ensheathing cells genetically modified to secrete GDNF to promote spinal cord repair. Brain 127:535-549.

Chuah MI, West AK (2002) Cellular and molecular biology of ensheathing cells. Microsc Res Tech 58:216-227.

Chuah MI, Choi-Lundberg D, Weston S, Vincent AJ, Chung RS, Vickers JC, West AK (2004) Olfactory ensheathing cells promote collateral axonal branching in the injured adult rat spinal cord. Exp Neurol 185: $15-25$.

Collazos-Castro JE, Muneton-Gomez VC, Nieto-Sampedro M (2005) Olfactory glia transplantation into cervical spinal cord contusion injuries. J Neurosurg Spine 3:308-317.

Dobkin BH, Curt A, Guest J (2006) Cellular transplants in china: observational study from the largest human experiment in chronic spinal cord injury. Neurorehabil Neural Repair 20:5-13.

Doucette JR, Kiernan JA, Flumerfelt BA (1983) The re-innervation of olfactory glomeruli following transection of primary olfactory axons in the central or peripheral nervous system. J Anat 137:1-19.

Doucette R (1990) Glial influences on axonal growth in the primary olfactory system. Glia 3:433-449.

Doucette R (1995) Olfactory ensheathing cells: potential for glial cell transplantation into areas of CNS injury. Histol Histopathol 10:503-507.

Faulkner JR, Herrmann JE, Woo MJ, Tansey KE, Doan NB, Sofroniew MV (2004) Reactive astrocytes protect tissue and preserve function after spinal cord injury. J Neurosci 24:2143-2155.

Fitch MT, Doller C, Combs CK, Landreth GE, Silver J (1999) Cellular and molecular mechanisms of glial scarring and progressive cavitation: in vivo and in vitro analysis of inflammation-induced secondary injury after CNS trauma. J Neurosci 19:8182-8198.

Fouad K, Schnell L, Bunge MB, Schwab ME, Liebscher T, Pearse DD (2005) Combining Schwann cell bridges and olfactory-ensheathing glia grafts with chondroitinase promotes locomotor recovery after complete transection of the spinal cord. J Neurosci 25:1169-1178.

Garcia-Alias G, Lopez-Vales R, Fores J, Navarro X, Verdu E (2004) Acute transplantation of olfactory ensheathing cells or Schwann cells promotes recovery after spinal cord injury in the rat. J Neurosci Res 75:632-641.

Geer CP, Grossman SA (1997) Interstitial fluid flow along white matter tracts: a potentially important mechanism for the dissemination of primary brain tumors. J Neurooncol 32:193-201.

Gomez VM, Averill S, King V, Yang Q, Perez ED, Chacon SC, Ward R, Nieto-Sampedro M, Priestley J, Taylor J (2003) Transplantation of olfactory ensheathing cells fails to promote significant axonal regeneration from dorsal roots into the rat cervical cord. J Neurocytol 32:53-70.

Graziadei PP, Monti Graziadei GA (1980) Neurogenesis and neuron regeneration in the olfactory system of mammals. III. Deafferentation and reinnervation of the olfactory bulb following section of the fila olfactoria in rat. J Neurocytol 9:145-162.

Hill CE, Moon LD, Wood PM, Bunge MB (2006) Labeled Schwann cell transplantation: cell loss, host Schwann cell replacement, and strategies to enhance survival. Glia 53:338-343.

Huang H, Chen L, Wang H, Xiu B, Li B, Wang R, Zhang J, Zhang F, Gu Z, Li 
Y, Song Y, Hao W, Pang S, Sun J (2003) Influence of patients' age on functional recovery after transplantation of olfactory ensheathing cells into injured spinal cord injury. Chin Med J (Engl) 116:1488-1491.

Imaizumi T, Lankford KL, Kocsis JD (2000a) Transplantation of olfactory ensheathing cells or Schwann cells restores rapid and secure conduction across the transected spinal cord. Brain Res 854:70-78.

Imaizumi T, Lankford KL, Burton WV, Fodor WL, Kocsis JD (2000b) Xenotransplantation of transgenic pig olfactory ensheathing cells promotes axonal regeneration in rat spinal cord. Nat Biotechnol 18:949-953.

Iwashita Y, Crang AJ, Blakemore WF (2000) Redistribution of bisbenzimide Hoechst 33342 from transplanted cells to host cells. NeuroReport 11:1013-1016.

Jani HR, Raisman G (2004) Ensheathing cell cultures from the olfactory bulb and mucosa. Glia 47:130-137.

Jones LL, Sajed D, Tuszynski MH (2003) Axonal regeneration through regions of chondroitin sulfate proteoglycan deposition after spinal cord injury: a balance of permissiveness and inhibition. J Neurosci 23:9276-9288.

Keyvan-Fouladi N, Raisman G, Li Y (2003) Functional repair of the corticospinal tract by delayed transplantation of olfactory ensheathing cells in adult rats. J Neurosci 23:9428-9434.

Lee IH, Bulte JW, Schweinhardt P, Douglas T, Trifunovski A, Hofstetter C, Olson L, Spenger C (2004) In vivo magnetic resonance tracking of olfactory ensheathing glia grafted into the rat spinal cord. Exp Neurol 187:509-516.

Li Y, Field PM, Raisman G (1997) Repair of adult rat corticospinal tract by transplants of olfactory ensheathing cells. Science 277:2000-2002.

Li Y, Field PM, Raisman G (1998) Regeneration of adult rat corticospinal axons induced by transplanted olfactory ensheathing cells. J Neurosci 18:10514-10524.

Li Y, Carlstedt T, Berthold CH, Raisman G (2004) Interaction of transplanted olfactory-ensheathing cells and host astrocytic processes provides a bridge for axons to regenerate across the dorsal root entry zone. Exp Neurol 188:300-308.

Li Y, Field PM, Raisman G (2005) Olfactory ensheathing cells and olfactory nerve fibroblasts maintain continuous open channels for regrowth of olfactory nerve fibres. Glia 52:245-251.

Liu Y, Kim D, Himes BT, Chow SY, Schallert T, Murray M, Tessler A, Fischer I (1999) Transplants of fibroblasts genetically modified to express BDNF promote regeneration of adult rat rubrospinal axons and recovery of forelimb function. J Neurosci 19:4370-4387.

Lopez-Vales R, Garcia-Alias G, Fores J, Navarro X, Verdu E (2004) Increased expression of cyclo-oxygenase 2 and vascular endothelial growth factor in lesioned spinal cord by transplanted olfactory ensheathing cells. J Neurotrauma 21:1031-1043.

Lopez-Vales R, Fores J, Verdu E, Navarro X (2006) Acute and delayed transplantation of olfactory ensheathing cells promote partial recovery after complete transection of the spinal cord. Neurobiol Dis 21: $57-68$.

Lu J, Feron F, Ho SM, Mackay-Sim A, Waite PM (2001) Transplantation of nasal olfactory tissue promotes partial recovery in paraplegic adult rats. Brain Res 889:344-357.

Lu J, Feron F, Mackay-Sim A, Waite PM (2002) Olfactory ensheathing cells promote locomotor recovery after delayed transplantation into transected spinal cord. Brain 125:14-21.

Lu P, Blesch A, Tuszynski MH (2001) Neurotrophism without neurotropism: BDNF promotes survival but not growth of lesioned corticospinal neurons. J Comp Neurol 436:456-470.

Lu P, Jones LL, Snyder EY, Tuszynski MH (2003) Neural stem cells constitutively secrete neurotrophic factors and promote extensive host axonal growth after spinal cord injury. Exp Neurol 181:115-129.

Lu P, Yang H, Jones LL, Filbin MT, Tuszynski MH (2004) Combinatorial therapy with neurotrophins and cAMP promotes axonal regeneration beyond sites of spinal cord injury. J Neurosci 24:6402-6409.

Lu P, Jones LL, Tuszynski MH (2005) BDNF-expressing marrow stromal cells support extensive axonal growth at sites of spinal cord injury. Exp Neurol 191:344-360.

Moreno-Flores MT, Bradbury EJ, Martin-Bermejo MJ, Agudo M, Lim F, Pastrana E, Avila J, Diaz-Nido J, McMahon SB, Wandosell F (2006) A clonal cell line from immortalized olfactory ensheathing glia promotes functional recovery in the injured spinal cord. Mol Ther 13:598-608.

Nash HH, Borke RC, Anders JJ (2002) Ensheathing cells and methylpred- nisolone promote axonal regeneration and functional recovery in the lesioned adult rat spinal cord. J Neurosci 22:7111-7120.

Navarro X, Valero A, Gudino G, Fores J, Rodriguez FJ, Verdu E, Pascual R, Cuadras J, Nieto-Sampedro M (1999) Ensheathing glia transplants promote dorsal root regeneration and spinal reflex restitution after multiple lumbar rhizotomy. Ann Neurol 45:207-215.

Pascual JI, Gudino-Cabrera G, Insausti R, Nieto-Sampedro M (2002) Spinal implants of olfactory ensheathing cells promote axon regeneration and bladder activity after bilateral lumbosacral dorsal rhizotomy in the adult rat. J Urol 167:1522-1526.

Pearse DD, Marcillo AE, Oudega M, Lynch MP, Wood PM, Bunge MB (2004) Transplantation of Schwann cells and olfactory ensheathing glia after spinal cord injury: does pretreatment with methylprednisolone and interleukin-10 enhance recovery? J Neurotrauma 21:1223-1239.

Plant GW, Christensen CL, Oudega M, Bunge MB (2003) Delayed transplantation of olfactory ensheathing glia promotes sparing/regeneration of supraspinal axons in the contused adult rat spinal cord. J Neurotrauma 20:1-16.

Polentes J, Stamegna JC, Nieto-Sampedro M, Gauthier P (2004) Phrenic rehabilitation and diaphragm recovery after cervical injury and transplantation of olfactory ensheathing cells. Neurobiol Dis 16:638-653.

Ramer LM, Au E, Richter MW, Liu J, Tetzlaff W, Roskams AJ (2004a) Peripheral olfactory ensheathing cells reduce scar and cavity formation and promote regeneration after spinal cord injury. J Comp Neurol 473:1-15.

Ramer LM, Richter MW, Roskams AJ, Tetzlaff W, Ramer MS (2004b) Peripherally-derived olfactory ensheathing cells do not promote primary afferent regeneration following dorsal root injury. Glia 47:189-206.

Ramon-Cueto A, Nieto-Sampedro M (1994) Regeneration into the spinal cord of transected dorsal root axons is promoted by ensheathing glia transplants. Exp Neurol 127:232-244.

Ramon-Cueto A, Plant GW, Avila J, Bunge MB (1998) Long-distance axonal regeneration in the transected adult rat spinal cord is promoted by olfactory ensheathing glia transplants. J Neurosci 18:3803-3815.

Ramon-Cueto A, Cordero MI, Santos-Benito FF, Avila J (2000) Functional recovery of paraplegic rats and motor axon regeneration in their spinal cords by olfactory ensheathing glia. Neuron 25:425-435.

Resnick DK, Cechvala CF, Yan Y, Witwer BP, Sun D, Zhang S (2003) Adult olfactory ensheathing cell transplantation for acute spinal cord injury. J Neurotrauma 20:279-285.

Richter MW, Fletcher PA, Liu J, Tetzlaff W, Roskams AJ (2005) Lamina propria and olfactory bulb ensheathing cells exhibit differential integration and migration and promote differential axon sprouting in the lesioned spinal cord. J Neurosci 25:10700-10711.

Riddell JS, Enriquez-Denton M, Toft A, Fairless R, Barnett SC (2004) Olfactory ensheathing cell grafts have minimal influence on regeneration at the dorsal root entry zone following rhizotomy. Glia 47:150-167.

Rosenberg GA, Kyner WT, Estrada E (1980) Bulk flow of brain interstitial fluid under normal and hyperosmolar conditions. Am J Physiol 238:F42-49.

Ruitenberg MJ, Plant GW, Christensen CL, Blits B, Niclou SP, Harvey AR, Boer GJ, Verhaagen J (2002) Viral vector-mediated gene expression in olfactory ensheathing glia implants in the lesioned rat spinal cord. Gene Ther 9:135-146.

Ruitenberg MJ, Plant GW, Hamers FP, Wortel J, Blits B, Dijkhuizen PA, Gispen WH, Boer GJ, Verhaagen J (2003) Ex vivo adenoviral vectormediated neurotrophin gene transfer to olfactory ensheathing glia: effects on rubrospinal tract regeneration, lesion size, and functional recovery after implantation in the injured rat spinal cord. J Neurosci 23:7045-7058.

Ruitenberg MJ, Levison DB, Lee SV, Verhaagen J, Harvey AR, Plant GW (2005) NT-3 expression from engineered olfactory ensheathing glia promotes spinal sparing and regeneration. Brain 128:839-853.

Sasaki M, Lankford KL, Zemedkun M, Kocsis JD (2004) Identified olfactory ensheathing cells transplanted into the transected dorsal funiculus bridge the lesion and form myelin. J Neurosci 24:8485-8493.

Steward O, Sharp K, Selvan G, Hadden A, Hofstadter M, Au E, Roskams J (2006) A re-assessment of the consequences of delayed transplantation of olfactory lamina propria following complete spinal cord transection in rats. Exp Neurol 198:483-499.

Takami T, Oudega M, Bates ML, Wood PM, Kleitman N, Bunge MB (2002) Schwann cell but not olfactory ensheathing glia transplants improve 
hindlimb locomotor performance in the moderately contused adult rat thoracic spinal cord. J Neurosci 22:6670-6681.

Tuszynski MH, Gabriel K, Gage FH, Suhr S, Meyer S, Rosetti A (1996) Nerve growth factor delivery by gene transfer induces differential outgrowth of sensory, motor, and noradrenergic neurites after adult spinal cord injury. Exp Neurol 137:157-173.

Verdu E, Garcia-Alias G, Fores J, Lopez-Vales R, Navarro X (2003) Olfactory ensheathing cells transplanted in lesioned spinal cord prevent loss of spinal cord parenchyma and promote functional recovery. Glia 42:275-286.

Weidner N, Ner A, Salimi N, Tuszynski MH (2001) Spontaneous corticospinal axonal plasticity and functional recovery after adult central nervous system injury. Proc Natl Acad Sci USA 98:3513-3518.
Williams SK, Franklin RJ, Barnett SC (2004) Response of olfactory ensheathing cells to the degeneration and regeneration of the peripheral olfactory system and the involvement of the neuregulins. J Comp Neurol 470:50-62.

Wood JD, Lonser RR, Gogate N, Morrison PF, Oldfield EH (1999) Convective delivery of macromolecules into the naive and traumatized spinal cords of rats. J Neurosurg 90:115-120.

Xu XM, Guenard V, Kleitman N, Bunge MB (1995) Axonal regeneration into Schwann cell-seeded guidance channels grafted into transected adult rat spinal cord. J Comp Neurol 351:145-160.

Zhang ET, Richards HK, Kida S, Weller RO (1992) Directional and compartmentalised drainage of interstitial fluid and cerebrospinal fluid from the rat brain. Acta Neuropathol (Berl) 83:233-239. 